\title{
NEW APPROACH TO OIL PALM WOOD UTILIZATION FOR WOODWORKING PRODUCTION Part 1: Basic Properties
}

\author{
Jamal Balfas ${ }^{i}$
}

\begin{abstract}
An explosive development in oil palm plantations in the country has produced a consequence in the generation of plantation wastes. The disposal of these wastes has created an enormous environmental problem that some practical solution to their economic utilization has to be sought. A series of experiments have been accomplished to observe the possibility of converting the oil palm stem into valuable woodworking products. The first stage of this effort was determining basic characteristics of oil palm wood. Results in general showed that the wood has a great characteristic variation across and along the stem, which may develop problems in its utilization. Characteristics of this wood also vary according to species variety. Quality degradations of oil palm wood were mostly happened during drying process; hence, modifications to upgrade quality should be undertaken before or within the drying process.
\end{abstract}

Keywords: Basic properties, oil palm wood, utilization, woodworking

\section{INTRODUCTION}

Unsustainable logging practices, illegal logging and fires have considerably degraded and reduced the area of land forest cover in the last three decades. The Forestry and Estate Crops Minister has given a warning sign to the Indonesian wood industry owners to prepare their industries in facing a new government policy regarding a reduction of timber exploitation level which would result in a national timber deficit of more than 25 million $\mathrm{m}^{3}$ annually (Sinaga, 1998). The policy would inevitably increase practices of illegal cutting in many regions of the country, therefore giving more pressure to the natural forests sustainability. National monetary problem and political turbulences arose in the last few years have also given significant contribution to the increase cases of uncontrolled and illegal felling. Apart of that, the dramatic increased of local timber prices in recent years is considered as another trigger augmenting the illegal practices.

Now a sustainable management and utilization of tropical forests is being forced to implementation in the country, with the combined main objectives of environmental conservation, land rehabilitation and generating more benefit from non wood forest products. This new paradigm would inevitably create enormous problem to the national wood industries, in terms of declined log supply. It will further affect reduction on wood based products, working opportunities, income earnings, etc. We are always faced with confronting risks and beneficiaries when applying any concept of forest management. There

${ }^{1}$ Forest Products Research and Development Center, Bogor 
are at least two alternatives to meet the above threats confronting us:

a) Avoid using wood

b) Look at alternate sources of wood without damaging the environment

The first alternative is almost impossible, as wood has become an integral part of life of human being, and substitute like plastics, etc., being non-bio degradable, have themselves become an environmental hazard. The only alternative left is the second one. The world has to look at substitutes, which can take the place of wood without affecting the environment. This is the reason why plantation trees, which necessarily have to be cut, after their yielding stage for re-plantation, have been identified as a renewable resource and a substitute.

Indonesia possesses a huge area of approximately 10 million hectares of coconut, rubber and oil palm plantations. Replanting old trees of the first two plantations could produce timber of more than 10 million $\mathrm{m}^{3}$ annually (Balfas, 1993), whereas the oil palm plantation could contribute some 23 million $\mathrm{m}^{3}$ logs per annum (Balfas, 1997). These figures would further increase in the future in accord with the great expansion of plantation areas in the last ten years, particularly the oil palm estates. Coconut and rubber wood have been intensively used in the last fifteen years for making various products of building components and woodworking. In contrast, the oil palm wood is traditionally disposed by burning or left to rot in the field.

Various researchers in several countries have given numerous attentions to determine ways of utilizing the oil palm stem. Results in general suggested that the oil palm stem is a novel material in the field of timber utilization and is not an easy material to process and work with. It has certain unique characteristics and proffers a vast array of problems that are rarely encountered in any conventional timber. Relationship of costs versus recovery rate and comparable quality of the woodworking products is disadvantageous for the processing of oil palm stems (Shaari et al., 1991). These studies, however, have adopted the existing techniques commonly used to process the conventional timbers. Since the last six years, The Forest Products Research and Development Center (FPRDC) has created a new approach in timber processing through several application of organic and inorganic modifications which significantly effective in improving the inferior characteristics of low-density timbers and the oil palm wood. The method gave a promising prospect of using the oil palm stem as substitute material for productions of furniture and building components. This article reports the early part of the study, which includes description of basic characteristics of oil palm wood.

\section{METHODOLOGY}

\section{A. Test Material}

Oil palm trees representing three varieties (Dura, Picivera and Tenera) were selected from three localities in the province of North Sumatra. The trees were selected according to the following criteria: representative sampling of the respective site, all height and diameter classes included, straight boles, and free of rot. The plantations from which sample trees were taken, were established in 1973 (age 27 years). All trees selected were numbered, felled and cut immediately below the crown. The clear boles were bucked into sections of $2.5 \mathrm{~m}$ 
length logs. Sample disks were taken at butt and breast height levels, and thereafter at $2.5 \mathrm{~m}$ intervals. Specimens for determination of moisture content and density distribution were cut from each disk within approximately 30 minutes after felling and bucking. Moisture specimens were divided into small blocks and processed immediately. Density specimens were carefully conditioned to equilibrium moisture content.

\section{B. Physical and Mechanical Properties}

Moisture content and density distribution from the outer part towards the center of the stem, and along the stem were determined for each species variety. Procedures used in these measurements followed the method described by Meylan (1978). Mechanical properties including bending, hardness, and compression strengths, were determined using a universal testing machine (Shimadzu, $100 \mathrm{KNe}$ ).

\section{Sawing Performance}

All oil palm logs were broken down using a band-headrig (BS-60"), and further processed in a band-resaw (BS-44"). Sawblades with tooth pitch of 40-45 mm were stellite tipped and operated at feed speed ranging from 8 to $15 \mathrm{~m} /$ minute. The outer (high density) and inner (lower density) part of each log was concentrated for producing 30 and $50 \mathrm{~mm}$ boards respectively. Hence, only one sawing pattern was initially used in this study, as shown in Figure 1. Parameters observed in this aspect include recovery, productivity and practicability of sawing process.

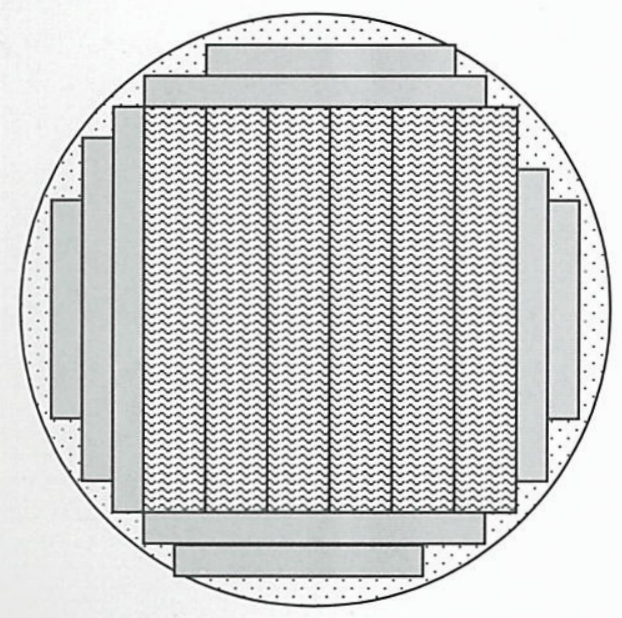

$30 \mathrm{~mm}$ boards

$50 \mathrm{~mm}$ boards

Figure 1. Sawing pattern used for producing 30 and $50 \mathrm{~mm}$ planks 


\section{Drying Characteristics}

Approximately 300 boards of each thickness size and species variety were used in drying experiments. Boards were divided into three groups and subsequently subjected to different drying method, namely air drying, preliminary air plus kiln drying, and simply kiln drying. Air drying experiments were conducted in an open shelter and started in the early dry season. Average temperature and humidity over the entire period was $26^{\circ} \mathrm{C}$ and $89 \%$ respectively. Boards were stacked on metal supports with ground clearance of $40 \mathrm{~cm}$. Drying quality was determined by measuring defects and dimensional changes after drying completion.

In the second drying method, the charge was subjected to 10 days preliminary air-drying. Kiln drying experiment was conducted with a local made semi-automatic chamber sizing $4 \times 2$ $\mathrm{x} 2 \mathrm{~m}$.

\section{E. Machining Tests}

Approximately $2 \mathrm{~m}^{3}$ of oil palm sawn timber of each species variety were prepared for machining tests. The tests include planning, shaping, boring and sanding operations. Conventional machineries fashioned to industry standards were used for conducting different testing operation. Testing procedures were carried out according to ASTMD.166664 (Anonym, 1974) with some modifications to satisfy several test requirements.

\section{RESULTS AND DISCUSSION}

Average physical dimensions of oil palm trunks significantly vary over species variety as shown in Table 1. Dura possesses greater sizes in height and diameter than the two other varieties. However, its number of trees remained at the replanting period was smaller than Tenera or Picivera. The average volume of oil palm trunks is $1.72 \mathrm{~m}^{3}$ per tree or $220 \mathrm{~m}^{3}$ per hectare. These figures are slightly lower than those reported by Shaari et al. (1991).

Table 1. Physical dimensions of oil palm trunks

\begin{tabular}{|l|c|c|c|c|c|}
\hline Variety & Diameter $(\mathrm{cm})$ & Height $(\mathrm{m})$ & Volume $\left(\mathrm{m}^{3}\right)$ & Trees/ha & Volume/ha $\left(\mathrm{m}^{3}\right)$ \\
\hline Dura & 48.59 & 11.80 & 2.19 & 125 & 273.75 \\
Picivera & 39.00 & 8.86 & 1.06 & 129 & 136.74 \\
Tenera & 46.65 & 11.20 & 1.91 & 131 & 250.21 \\
\hline Average & 44.75 & 10.62 & 1.72 & 128 & 220.16 \\
\hline
\end{tabular}


Green moisture content of oil palm wood varies from 80 to $380 \%$ depending on species variety, as well as radial and longitudinal positions. Dura (as shown in Figure 2 and 3) consistently has a lower initial moisture content than Tenera and Picifera. The first two varieties have a similar pattern in moisture content distribution both radially and longitudinally. The pattern in general shows that oil palm wood moisture content gradually increases along the stem height and towards the central region. Values of average moisture content recorded in this study are much lower than those described by Shaari et al. (1991), but the distribution patterns across and along the stem are approximately the same. The decreased initial moisture content from core outward and from butt upward may have a close relationship with the lower portion of parenchymatous tissues in each direction ( $\mathrm{Lim}$ and Khoo, 1986).

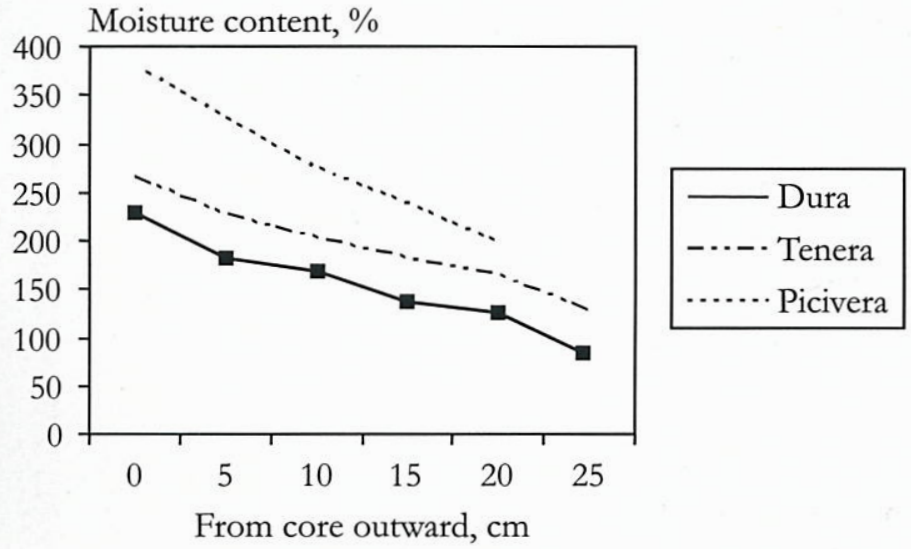

Figure 2. Moisture content distribution across the stem

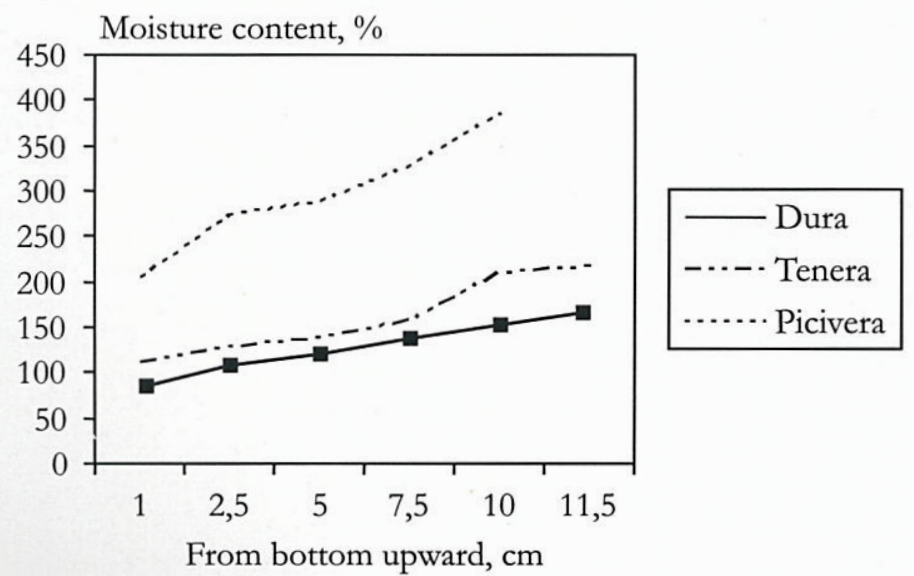

Figure 3. Moisture content distribution along the stem 
Air-dry density of the three oil palm varieties also shows a great variation across and along the stem (Figure 4 and 5). Density values range from 0.21 (inner part of Picivera) to 0.67 (outer part of Dura). This variable increases markedly from core outwards and decreased proportionally with stem height. The radial increments from periphery towards the core are logarithmic (Figure 4), whereas the corresponding changes from butt upwards follow a linear function (Figure 5). These variations, according to Killmann and Lim (1985), are primarily due to several anatomical reasons, such as vascular bundles, fibrous sheaths, cell walls of ground parenchyma and fibres.

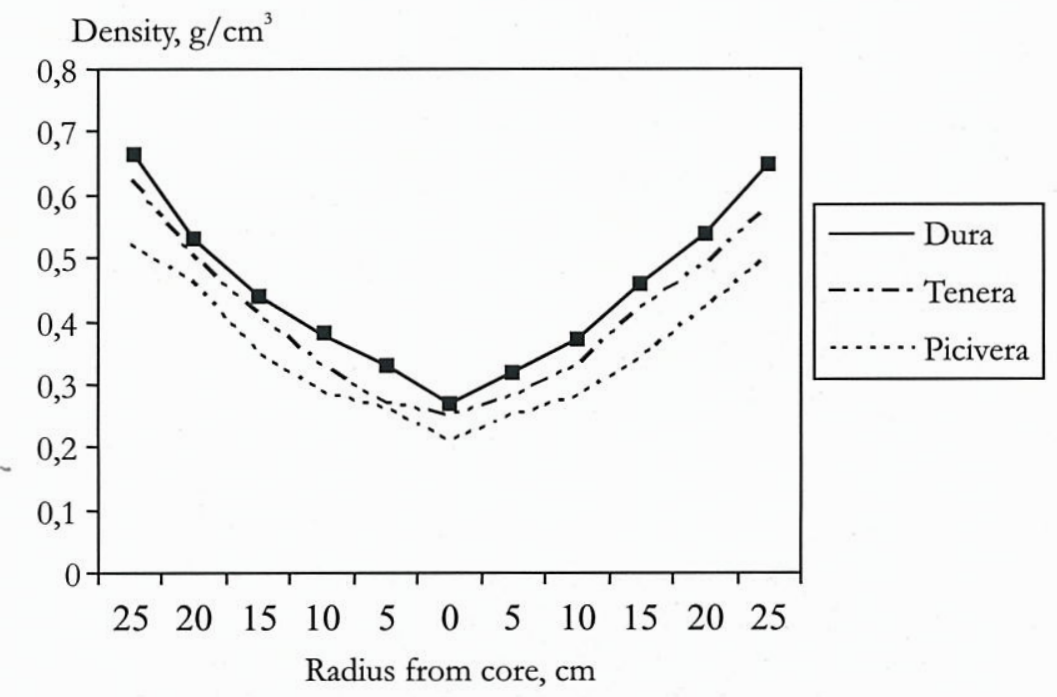

Figure 4. Density distribution across the stem

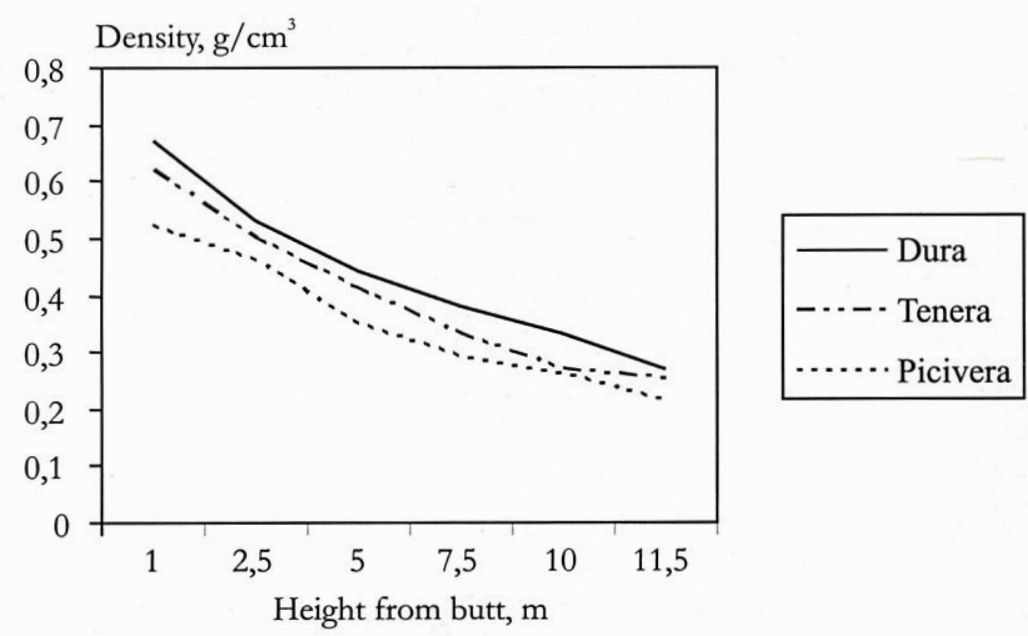

Figure 5. Density distribution along the stem 
Mechanical properties of oil palm wood reflect the density variations discussed above in radial as well as vertical direction. The properties also vary markedly according to species variety; Dura consistently reveals better mechanical properties than Tenera and Picivera (Table 2). Comparison of mechanical properties of oil palm wood with three other species listed in the table clearly shows that values of the former are approximately 10 to $60 \%$ lower.

Table 2. Mechanical properties

\begin{tabular}{|l|l|c|c|c|c|c|}
\hline $\begin{array}{c}\text { Species } \\
\text { variety }\end{array}$ & $\begin{array}{c}\text { Part of } \\
\text { stem }\end{array}$ & $\begin{array}{c}\text { Density } \\
\left(\mathrm{g} / \mathrm{cm}^{3}\right)\end{array}$ & $\begin{array}{c}\mathrm{MOE} \\
\left(\mathrm{kg} / \mathrm{cm}^{2}\right)\end{array}$ & $\begin{array}{c}\text { MOR } \\
\left(\mathrm{kg} / \mathrm{cm}^{2}\right)\end{array}$ & $\begin{array}{c}\text { Comp.// to } \\
\mathrm{Grain}\left(\mathrm{kg} / \mathrm{cm}^{2}\right)\end{array}$ & $\begin{array}{c}\text { Hardness } \\
(\mathrm{kg})\end{array}$ \\
\hline Dura & Butt* & 0.67 & 87,627 & 763 & 544 & 427 \\
& Middle & 0.42 & 41,640 & 321 & 226 & 197 \\
\hline Tenera & Butt* & 0.63 & 84,448 & 725 & 529 & 414 \\
& Middle & 0.39 & 35,720 & 317 & 212 & 185 \\
\hline Picifera & Butt* & 0.52 & 61,441 & 596 & 488 & 384 \\
& Middle & 0.33 & 32,815 & 288 & 172 & 160 \\
\hline $\begin{array}{l}\text { Coconut } \\
\text { wood** }\end{array}$ & Butt & $>0.60$ & 115,200 & 989 & 582 & 558 \\
\hline $\begin{array}{l}\text { Rubber } \\
\text { wood** }\end{array}$ & - & 0.56 & 91,050 & 652 & 271 & 442 \\
\hline $\begin{array}{l}\text { Merkusii } \\
\text { pine** }\end{array}$ & - & 0.54 & 88,422 & 630 & 268 & 429 \\
\hline
\end{tabular}

Remarks: * At breast height $(1,5 \mathrm{~m})$; ** Laboratory notes, Forest Products Research and Development Center; MOE: Modulus of elasticity; MOR:Modulus of rupture; Comp. //: Compression parallel

Dura and Tenera show comparable sawing performances in almost all variables observed in this aspect (Table 3). Picivera indicates a lower sawing performance than the first two varieties. The quantitative difference is particularly due to the smaller log diameters of the last variety. Part of stem affected many variations in sawing process. Butt logs possess better sawing recovery, quality and productivity than those of the upper parts. These superiorities are correlated with the bigger log diameters and better wood structure of the butt logs. With an exception of sawn timber surface quality, the oil palm wood in general shows comparable sawing performances with coconut wood, rubber wood and Merkusii pine. However, it should be noticed that oil palm sawing requires more blade replacements due to a quick dulling of the saw teeth.

Drying characteristics of oil palm sawn timber using different methods are summarized in Table 4. Results showed that the characteristics were significantly affected by species variety, part of stem, board thickness and drying method. Dura generally dried quicker and suffered less drying defects than the other two varieties. This could be related to its lower initial moisture contents (Figure 2\&3) and higher wood densities (Figure 4\&5) as discussed earlier. Similar phenomenon was also seen at different parts of stem. Sawn timber extracted 
from butt logs had better drying characteristics than those extracted from the upper logs. Thicker boards dried slower and suffered more serious drying defects than the thinner ones. This could be understood because the thicker boards were extracted from the inner parts of logs (Figure 1), which markedly had higher initial moisture contents and lower densities, hence, they required a longer period to dry and more prone to suffer from drying defects. The use of kiln dryer after preliminary air-drying could reduce drying period of more than fifty percent of the total time required in air-drying process. The third method, i.e. drying oil palm sawn timber simply using kiln dryer could further shorten drying period up to 12 days.

Physical and biological defects developed during drying became the most serious problems to be considered in the utilization of oil palm wood. Almost $80 \%$ of the total boards used in drying experiments suffered from various defects, including twist, surface checks, warping, collapse, and biodegradation (particularly fungal and insect attacks). Most of defective boards were those having lower densities or taken from the inner and upper parts of the stem.

Tabel 3. Sawing performances

\begin{tabular}{|c|c|c|c|c|c|c|c|}
\hline $\begin{array}{l}\text { Species } \\
\text { variety }\end{array}$ & $\begin{array}{c}\text { Part of } \\
\text { stem }\end{array}$ & $\begin{array}{c}\text { Log } \\
\text { diameter } \\
(\mathrm{cm})\end{array}$ & $\begin{array}{c}\text { Recovery } \\
(\%)\end{array}$ & $\begin{array}{l}\text { Surface } \\
\text { quality }\end{array}$ & $\begin{array}{c}\text { Surface } \\
\text { area } \\
\left(\mathrm{m}^{2}\right) \\
\text { per hour }\end{array}$ & $\begin{array}{c}\text { Feed } \\
\text { speed } \\
(\mathrm{m} / \\
\text { minute) }\end{array}$ & $\begin{array}{c}\text { Productivity } \\
\left(\mathrm{m}^{3} / \text { hour }\right)\end{array}$ \\
\hline Dura & $\begin{array}{l}\text { Butt* } \\
\text { Middle } \\
\text { Top }\end{array}$ & $\begin{array}{l}48 \\
43 \\
37\end{array}$ & $\begin{array}{l}76 \\
74 \\
64\end{array}$ & $\begin{array}{c}\text { Mostly fine } \\
\text { Fine \& rough } \\
\text { Rough }\end{array}$ & $\begin{array}{l}43 \\
41 \\
42\end{array}$ & $\begin{array}{l}15 \\
14 \\
14\end{array}$ & $\begin{array}{l}2,42 \\
2,13 \\
1,87\end{array}$ \\
\hline Tenera & $\begin{array}{l}\text { Butt* } \\
\text { Middle } \\
\text { Top }\end{array}$ & $\begin{array}{l}45 \\
41 \\
34\end{array}$ & $\begin{array}{l}74 \\
70 \\
63\end{array}$ & $\begin{array}{c}\text { Mostly fine } \\
\text { Fine \& rough } \\
\text { Rough }\end{array}$ & $\begin{array}{l}45 \\
43 \\
42\end{array}$ & $\begin{array}{l}16 \\
14 \\
14\end{array}$ & $\begin{array}{l}2,48 \\
2,21 \\
1,92\end{array}$ \\
\hline Picifera & $\begin{array}{l}\text { Butt* } \\
\text { Middle } \\
\text { Top }\end{array}$ & $\begin{array}{l}39 \\
32 \\
29\end{array}$ & $\begin{array}{l}67 \\
62 \\
51\end{array}$ & $\begin{array}{l}\text { Fine \& rough } \\
\text { Rough } \\
\text { Mostly Rough }\end{array}$ & $\begin{array}{l}43 \\
40 \\
38\end{array}$ & $\begin{array}{l}15 \\
14 \\
13\end{array}$ & $\begin{array}{l}2,04 \\
1,89 \\
1,62\end{array}$ \\
\hline $\begin{array}{l}\text { Coconut } \\
\text { wood }^{* *}\end{array}$ & - & 21 & 47 & Fine & 32 & 12 & 1,21 \\
\hline $\begin{array}{l}\text { Rubber } \\
\text { wood** }\end{array}$ & - & 35 & 34 & Fine & 42 & 23 & 1,08 \\
\hline $\begin{array}{l}\text { Merkusii } \\
\text { pine** }^{* *}\end{array}$ & - & 38 & 56 & Fine & 51 & 25 & 1,84 \\
\hline
\end{tabular}

Remarks: * At breast height (1,5 m); ** Laboratory notes, Forest Products Research and Development Center 
Table 4. Drying properties

\begin{tabular}{|c|c|c|c|c|c|c|c|c|}
\hline \multirow{2}{*}{$\begin{array}{l}\text { Species } \\
\text { variety }\end{array}$} & \multirow{2}{*}{$\begin{array}{c}\text { Part of } \\
\text { stem }\end{array} \mid$} & \multirow{2}{*}{$\begin{array}{l}\text { Thick- } \\
\text { ness }\end{array}$} & \multirow{2}{*}{$\begin{array}{l}\text { Initial } \\
\mathrm{MC} \\
(\%)\end{array}$} & \multirow{2}{*}{$\begin{array}{c}\text { Final MC } \\
(\%)\end{array}$} & \multicolumn{3}{|c|}{$\begin{array}{l}\text { Time to dry } \\
\text { (days) }\end{array}$} & \multirow{2}{*}{$\begin{array}{l}\text { Drying } \\
\text { defects }\end{array}$} \\
\hline & & & & & A & B & $\mathrm{C}$ & \\
\hline \multirow[t]{6}{*}{ Dura } & \multirow{2}{*}{ Butt* } & $30 \mathrm{~mm}$ & $78-84$ & $16-18$ & 46 & 20 & 12 & \multirow{2}{*}{$\begin{array}{c}\text { Light twist, light checks } \\
\text { Twist, light collapse, } \\
\text { checks }\end{array}$} \\
\hline & & $50 \mathrm{~mm}$ & $118-121$ & $17-23$ & 65 & 22 & 15 & \\
\hline & \multirow[t]{2}{*}{ Middle } & $30 \mathrm{~mm}$ & $138-146$ & $17-20$ & 48 & 24 & 16 & \multirow{2}{*}{$\begin{array}{c}\text { Twist, checks, collapse } \\
\text { Severe twist, collapse, } \\
\text { checks }\end{array}$} \\
\hline & & $50 \mathrm{~mm}$ & $154-169$ & $17-25$ & 67 & 26 & 16 & \\
\hline & \multirow[t]{2}{*}{ Top } & $30 \mathrm{~mm}$ & $155-162$ & $17-22$ & 78 & 25 & 17 & \multirow{2}{*}{$\begin{array}{l}\text { Severe twist, collapse, } \\
\text { checks Severe twist, } \\
\text { collapse, checks }\end{array}$} \\
\hline & & $50 \mathrm{~mm}$ & $191-204$ & $19-28$ & 89 & 28 & 19 & \\
\hline \multirow[t]{6}{*}{ Tenera } & \multirow[t]{2}{*}{ Butt* } & $30 \mathrm{~mm}$ & $85-92$ & $16-18$ & 49 & 22 & 14 & \multirow{2}{*}{$\begin{array}{l}\text { Light twist, light checks } \\
\text { Twist, light collapse, } \\
\text { checks }\end{array}$} \\
\hline & & $50 \mathrm{~mm}$ & $129-142$ & $17-23$ & 68 & 23 & 17 & \\
\hline & \multirow[t]{2}{*}{ Middle } & $30 \mathrm{~mm}$ & $154-176$ & $17-20$ & 52 & 25 & 18 & \multirow{2}{*}{$\begin{array}{c}\text { Twist, checks, collapse } \\
\text { Severe twist, collapse, } \\
\text { checks }\end{array}$} \\
\hline & & $50 \mathrm{~mm}$ & $178-204$ & $17-25$ & 71 & 27 & 19 & \\
\hline & \multirow[t]{2}{*}{ Top } & $30 \mathrm{~mm}$ & $147-177$ & $17-22$ & 83 & 26 & 17 & \multirow{2}{*}{$\begin{array}{l}\text { Severe twist, collapse, } \\
\text { checks Severe twist, } \\
\text { collapse, checks }\end{array}$} \\
\hline & & $50 \mathrm{~mm}$ & $189-228$ & $19-28$ & 88 & 28 & 20 & \\
\hline \multirow[t]{6}{*}{ Picifera } & \multirow[t]{2}{*}{ Butt* } & $30 \mathrm{~mm}$ & $142-162$ & $16-18$ & 54 & 24 & 17 & \multirow{2}{*}{$\begin{array}{l}\text { Twist, light collapse, } \\
\text { checks } \\
\text { Twist, collapse, checks }\end{array}$} \\
\hline & & $50 \mathrm{~mm}$ & $177-219$ & $17-23$ & 76 & 29 & 21 & \\
\hline & \multirow[t]{2}{*}{ Middle } & $30 \mathrm{~mm}$ & $150-188$ & $17-20$ & 61 & 25 & 18 & \multirow{2}{*}{$\begin{array}{l}\text { Severe twist, checks, } \\
\text { collapse } \\
\text { Severe twist, collapse, } \\
\text { checks }\end{array}$} \\
\hline & & $50 \mathrm{~mm}$ & $196-272$ & $17-25$ & 85 & 31 & 23 & \\
\hline & \multirow[t]{2}{*}{ Top } & $30 \mathrm{~mm}$ & $189-236$ & $17-22$ & 107 & 30 & 22 & \multirow{2}{*}{$\begin{array}{l}\text { Severe twist, collapse, } \\
\text { checks } \\
\text { Severe twist, collapse, } \\
\text { checks }\end{array}$} \\
\hline & & $50 \mathrm{~mm}$ & $251-312$ & $19-28$ & 122 & 33 & 24 & \\
\hline
\end{tabular}

Remarks: * At breast height (1,5 m); MC = Moisture content; $\mathrm{A}=$ Air-drying; $\mathrm{B}=$ Preliminary air-drying plus kiln drying; $C=$ Kiln drying 
Oil palm wood was generally difficult to work with conventional tools. Table 5 showed values of defect free portion of oil palm wood after machining operations. Although Dura revealed better machining qualities than two other varieties, these wood materials as a whole possessed relatively poor machining characteristics compared with some commercial wood species. Boards from butt logs significantly produced better machining quality than those of the middle part of stem. This indicated a possible relationship between poor machining and the presence of larger portion of non-structural (parenchymatous) tissues. The use of tungsten carbide tipped tools to some extent could improve machining qualities of oil palm wood.

Table 5. Machining characteristics

\begin{tabular}{|c|c|c|c|c|c|}
\hline \multirow{2}{*}{$\begin{array}{l}\text { Species } \\
\text { variety }\end{array}$} & \multirow{2}{*}{$\begin{array}{c}\text { Part of } \\
\text { stem }\end{array}$} & \multicolumn{4}{|c|}{ Average defect free $(\%)$} \\
\hline & & Planing & Shaping & Boring & Sanding \\
\hline \multirow[t]{2}{*}{ Dura } & Butt* & 62.3 & 51.1 & 42.0 & 67.4 \\
\hline & Middle & 41.9 & 32.6 & 23.5 & 52.7 \\
\hline \multirow[t]{2}{*}{ Tenera } & Butt* & 52.5 & 48.7 & 38.3 & 61.3 \\
\hline & Middle & 36.7 & 30.1 & 21.2 & 46.3 \\
\hline \multirow[t]{2}{*}{ Picifera } & Butt* & 43.1 & 34.2 & 27.7 & 49.8 \\
\hline & Middle & 23.5 & 19.2 & 14.6 & 36.1 \\
\hline \multirow[t]{2}{*}{ Coconut wood** } & Butt & 75.7 & 62.5 & 54.5 & 78.7 \\
\hline & Middle & 58.3 & 45.6 & 40.7 & 63.5 \\
\hline Rubber wood** & - & 82.3 & 73.2 & 66.8 & 85.2 \\
\hline Merkusii pine** & - & 84.6 & 79.4 & 72.8 & 87.1 \\
\hline
\end{tabular}

Remarks: * At breast height (1,5 m); ** Laboratory notes, Forest Products Research and Development Center

\section{CONCLUSION}

Oil palm wood is a unique material with great characteristic variations across and along the stem, which may develop problems in its utilization. Such variations were not commonly encountered in conventional wood materials. Characteristics of this new wood also varied according to species variety. Quality degradations of oil palm wood were mostly happened during drying process; hence, modifications to upgrade quality should be done before or within the process.

\section{REFERENCES}

Anonym. 1974. Standard method of conducting machining tests of wood and wood-base materials. Annual Book of ASTM. Philadelphia. 
Anonym. 1995. Annual book of ASTM standards. Sect. 4. Vol 04.10-wood. Philadelphia.

Balfas, J. 1993. Status of research and development on rubberwood in Indonesia. International Forum on Investment Opportunities in the Rubberwood Industry, Kuala Lumpur, Malaysia.

Balfas, J. 1997. Sifat dasar kayu sawit. Makalah utama dalam Seminar Hasil Penelitian Balai Penelitian Kehutanan Pematang Siantar. Medan.

Killmann, W. and S.C. Lim. 1985. Anatomy and properties of oil palm stem. Proceedings of the National Symposium of Oil Palm By-products for Agro-based Industries. PORIM Bulletin No.11. Kuala Lumpur.

Lim, S.C. and K.C. Khoo. 1986. Characteristics of oil palm trunk and its potential utilization. The Malaysian Forester 49(1):3-22. Kuala Lumpur.

Meylan, B.A. 1978. Density variation within Cocos nucifera stems. New Zealand Journal of Forestry Science 8(3):369-383. Rotorua.

Shaari, K., K.K. Choon, and A.R.M. Ali. 1991. Oil palm stem-Review of research. Research Pamphlet No. 107. Forest Research Institute, Malaysia. Kuala Lumpur.

Sinaga, S. 1998. Overexploite teak forests revived attention. Asian Timber 17(12):20-22. Singapore. 
;

z 